Historic, Archive Document

Do not assume content reflects current scientific knowledge, policies, or practices. 



\title{
PRICE LIST FOR SPRING OF 1926
}

\author{
$-\mathrm{OF}-$ \\ The Linn County
}

Nurseries SNYDER BROS., Inc.

Center Point, Iowa ESTABLISHED 1895

GROWERS OF EVERGREENS FRUIT TREES NUT TREES PEONIES IRIS 


\section{FOREWORD}

IOCATION. Our nurseries are located on Primary Road No. 11, just south of the C., R. I. \& P. and W., C. F. \& N. Stations, so are easily reached by rail or motor car. Our orchards and testing grounds are on Primary Road No. 11, two miles southeast of the nursery.

PACKING FACILITIES. These consist of a clay block building 100 feet square. Boxes and bales are well papered and the roots protected with moist packing. Evergreens and large trees are dug only as they are sent out.

GUARANTEE. We exercise great care to keep our varieties true to name and are ready at any time, upon satisfactory proof, to replace any stock that may prove untrue, or to refund the amount paid for the same, but it is mutually agreed that we are not to be held liable for any amount greater than the original price paid for the stock.

CONDITIONS. All orders are accepted on condition that they shall be void should any injury befall the stock from hail, frost, fire, or other causes beyond our control. Deliveeries are subject to delay by bad weather, bad roads, strikes, accidents, embargoes and causes beyond our control.

TERMS are cash on or before the delivery of the stock, unless previously otherwise agreed upon.

CLAIMS for errors or shortage must be made immediately upon the receipt of the stock.

PRICES given are for the stock, properly packed and delivered at the Nursery, the stations here, or at nearby towns in case we are making a general delivery there. Small plants will be sent by parcel post within the second zone or the third zone if not too heary.

VISITORS WELCOME. We are always pleased to show visitors about the place if time to do so is available. During the packing and shipping season it is not always possible to give visitors the time we would like to. Trees may be selected and tagged at any time of year for delivery at the proper time. Evergreens over nine feet high should be tagged before freezing weather so a frozen ball of earth can be moved with them.

VARIETIES NOT LISTED IN THIS CATALOG. We have some trees and plants of many kinds not listed in this catalog. If you do not see what you want, write us. 


\section{APPLES}

Apple trees should be planted 30x30 feet apart. They respond to good cultivation and care as freely as does corn or any other crop. Our trees are graded according to the standard rules of grading. The 5 to $6 \mathrm{ft}$. size caliper $\frac{11}{16} \mathrm{in}$. and up; the other sizes $5 / 8$ to $\frac{11}{16}$ in. and $1 / 2$ to $5 / 8$ in., respectively. Many varieties will run considerably taller than rated.

The following is a list of the main varieties of apples we have this spring, arranged approximately in the order of their ripening:

\section{EARLY VARIETIES}

Liveland (Lowland Raspberry)

Duchess (Oldenburg)

Summer Pear

Yellow Transparent

Benoni

Chenango Strawberry

\section{FALL VARIETIES}

University

Bailey Sweet

Anism

MeIntosh

Delicious

Jonathan

Grimes (Golden)

King David

Banana (Winter)

Golden Russet

Sheriff

Isherwood
Brilliant

Wealthy
Snow (Fameuse)

Wolf River

Longfield

\section{WINTER VARIETIES}

$\begin{array}{ll}\text { Paradise W. Sweet } & \text { Cotta } \\ \text { Windsor } & \text { Allen.'s Choice } \\ \text { Iowa Blush } & \text { Salome } \\ \text { Tolman Sweet } & \text { Gano } \\ \text { Northern Spy } & \text { Black Ben Davis } \\ \text { N. W. Greening } & \text { Ben Davis } \\ \text { Wagoner } & \text { Nelson Sweet } \\ \text { Stayman (Winesap) } & \text { Malinda , } \\ \text { Roman Stem } & \text { Rall's (Janet or Geniton) }\end{array}$

\section{CRAB APPLE}

Hyslop

Whitney (No. 20)

Transcendant

Sweet Russet

Martha

Wild Red

Virginia

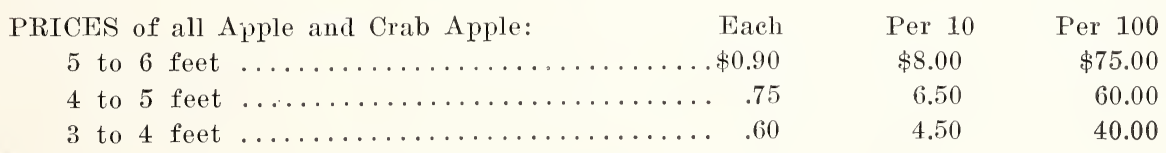

\section{PEACHES}

Peaches in central Iowa should be planted where they will have as much protection as possible.

Leading varieties-Champion, Bokära and Elberta. PRICES-

Budded tree

Bailey Seedlings
4 to $5 \mathrm{ft}$.
3 to $4 \mathrm{ft}$.
3 to $4 \mathrm{ft}$.

Each

$\$ 0.60$

.45

.20
Per 10

$\$ 5.00$

4.00 


\section{PEARS}

More than one variety should be planted to insure pollination. In the standard or large growing trees, we have the following:

$\begin{array}{lll}\text { Garber } & \text { Seckel } & \text { Clapp's Farorite } \\ \text { Flemish Beauty } & \text { Kieffer } & \text { Bartlett } \\ \text { Wilder } & \text { Longworth } & \text { Patten }\end{array}$
All standard Pears:

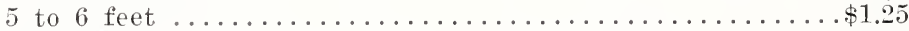

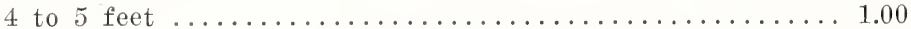

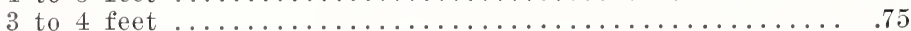
Per 10

DWARF PEARS are grafted on Quince roots, which dwarf and bring them into bearing earlier. We have the following varieties in the 4 to 5 and 3 to 4 foot sizes only:

\begin{tabular}{|c|c|c|}
\hline Bartlett & Seckel & Anjou \\
\hline Duchess & Kieffer & Clapp's Favorite \\
\hline $\begin{array}{l}\text { All Dwarf Pears- } \\
4 \text { to } 5 \text { feet ... }\end{array}$ & & $\begin{array}{l}\text { Each } \\
. \$ 1.00\end{array}$ \\
\hline 3 to 4 feet & &.$\quad .75$ \\
\hline
\end{tabular}

\section{CHERRIES}

(In order of their ripening)
Dyehouse
Montmorency
Baldwin
Early Richmond
Ostheime
Yellow Glass

\section{Wragg \\ English Morello}

Early Richmond and Montmorency are the most dependable and the most planted. Yellow Glass is a true, sweet cherry and is more tender than the others. Wragg and English Morello are very late and rery dark in color.
Above varieties except Yellow Glass-
Each

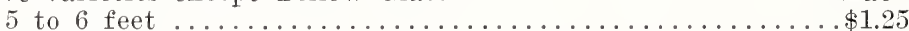

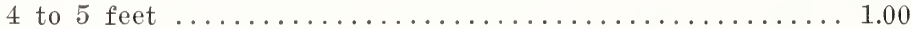
Per 10
$\$ 10.00$
9.00

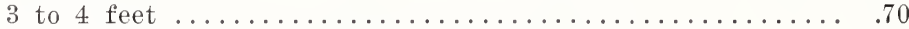
6.00
Yellow Glass 25c each higher on each grade.

\section{PLUIMS-Standard Varieties}

$\begin{array}{llll}\text { Abundance } & \text { Desoto } & \text { Lombard } & \text { Surprise } \\ \text { Burbank } & \text { Fellenburg } & \text { Miner } & \text { Terry } \\ \text { Compass } & \text { German Prune } & \text { Omaha } & \text { Toka } \\ \text { Communia } & \text { Gold } & \text { Opata } & \text { Wachampa } \\ \text { Damson } & \text { Hanska } & \text { Sapa } & \text { Waneta }\end{array}$

Terry, Surprise, and Desoto are all pure American varieties of splendid quality for all purposes, and we believe most dependable of all for the far north.

Abundance and Burbank are Japanese varieties, which are much prized by some, but usually overbear and are short-lived here.

Sapa, Opata, and Wachampa are all hybrids of the western Sand Cherry produced by Professor Hansen, and all make very crooked trees. Sapa is of medium size, has purplish flesh, a very small pit, and is very fine for canning. Wachampa is very similar to Sapa except the flesh is a lighter color. Opata has green flesh and is very early, but not especially good for cooking.

Hanska and Toka are also hybrids produced by Professor Hansen and generally included in the group known as the Hansen Hybrids. They are crosses of the American Plum and Prunus Simoni. Both varieties are very straight, symmetrical, upright trees. The fruit is bright red, of good size, and has a very pronounced apricot fragrance and flavor. Many people think them the best plums in our whole list. 
Omaha and Waneta are very productive hybrids more especially valued for eating from the tree, for which purpose there are a few varieties equal to Omaha.

Communia, Damson, German Prune, Fellenburg or Italian Prune, and Lombard are all European varieties often spoken of as blue plums.

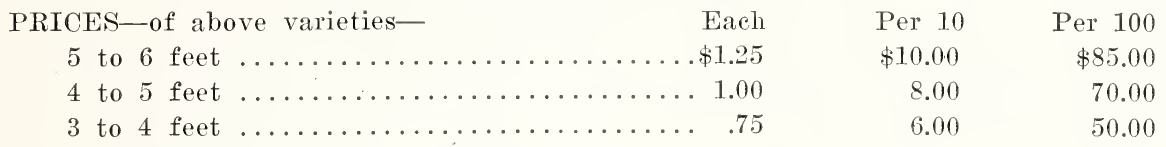

\section{PLUMS-New or Rare Varieties}

Beatty

X Bohemian Prune

Hennepin

$x$ Mary

Beatty is a local variety. It is very much prized by people who know it. The fruit is long, yellow and red in color and very excellent for all purposes. The tree grows in an inverted pyramidal form.

Wyckoff is a variety of medium size and light red color with a very thin skin and especially fine for canning, no other variety excelling it for this purpose .

Mary is a European plum belonging to the Green Gage type. It has proved very productive and the plums are perhaps the sweetest of any variety we have. They are a clear green color, which they hold in canning.

Bohemian Prune is one of the hardiest European varieties and the best real prune we have tested so far.

Hennepin, Red Wing, Monitor, Underwood, and Winona are a new group of plums which recently originated at the Minnesota State Fruit Breeding Farm. They are all large or very large and excellent varieties.

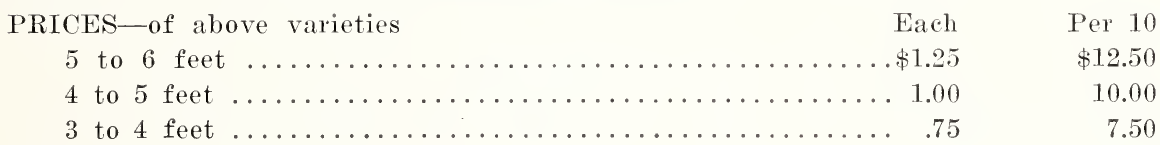

\section{GRAPES \\ (In order of ripening)}

Beta, black

Hungarian, black

Moore's Early, black

Moore's Diamond, white

Wyoming, red

\begin{abstract}
Elvira, white
Worden, black

Delaware, red

Lucile, red

Niagara, white
\end{abstract}

Lutie

Concord, black

Woodruff, red

Agawan, red

Beta, Hungarian and Elvira are small grapes, but very hardy and well suited for arbors and pergolas.

Concord is the best shipping variety and predominates in commercial plantings.

Worden and Moore's Early are larger and sweeter than Concord and should be included in the home vineyard.

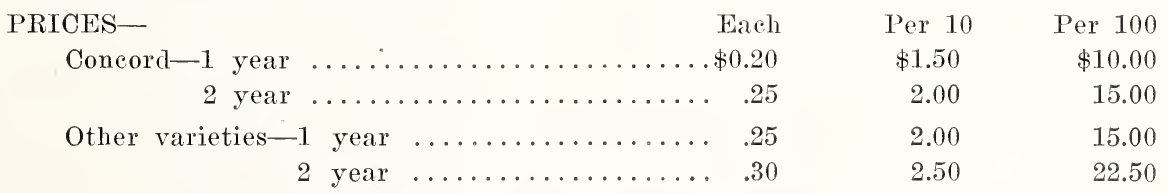




\section{CURRANTS} Iowa.

Currants cannot be sent across the quarantine line, which is the western line of

Tictoria

Wilder
Perfection

Diplona
2-Year Bushes-
Eacll

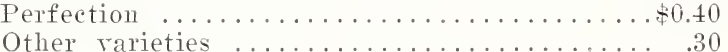

$\begin{array}{cr}\text { Per } 10 & \text { Per } 100 \\ \text { \$3.50 } & \$ 30.00 \\ 2.50 & 17.50\end{array}$

White Grape

Cherry

\section{GOOSEBERRIES}

Subject to the same quarantine as Currants.
Champion
Downing
Pearl

PRICES-2-year plants

Carrie
toe each $\$ 3.00$ per 10

\section{JUNEBERRIES}

Juneberry bushes are highly ornamental at all seasons of the year as well as being valuable for their fruit, which is much liked by the birds and attracts them from other berries and the cherries. Planted in a hedge row they will make an oval hedge 6 to 8 feet high and about that width.
PRICES-For Transplants
Each
12 to 18 inch bushes .......................... $\ldots .20$

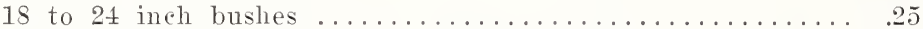
Per 10
$\$ 1.50$
2.00

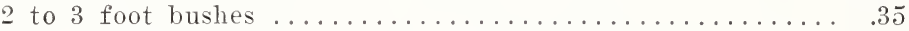
3.00
3 to 4 foot bushes ......................... . 0
4.00

\section{RASPBERRIES}

The purple and black varieties grow from tips, red ones from suckers. For home use the purple caps will motuce more fruit than the others.

Cumberland is the most planted of the black caps.

Latham is far the best and most profitable of the red varieties. Plant in hedge rows about two feet apart in the rows.

Columbian, purple

Cardinal, purple

Cumberland, black

Gregg, black
St. Regis, red everbearing King, red
Kansas, black
Louden, rea
Havmaker, purple

Roval Purple, purple
PRICES-
Per 10
Purple varieties and Latham ...........\$0.75
Other varieties ....................40
Per $100 \quad$ Per 1000
$\$ 6.00 \$ 50.00$
$3.00 \quad 25.00$

\section{BLACKBERRIES AND DEWBERRIES}

We have found the Snyder Blackberry the most dependable of many kinds tried and confine our growing to it. All the plants offered are root cutting plants; none are suckers from an old run-out patch.

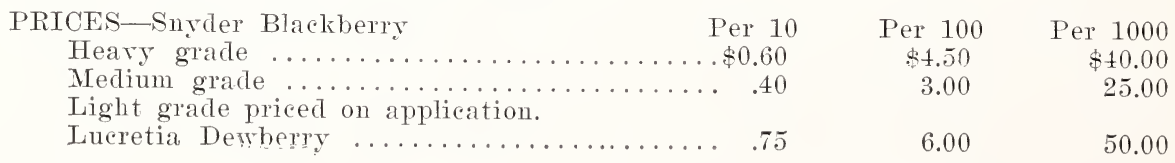




\section{STRAWBERRIES}

The Dunlap Strawberry succeeds so well under so many different conditions and is so good for all purposes that we advise it as the best spring bearing variety for general planting. Put out a new bed each year in rows $3 \frac{1}{2}$ to 4 feet apart and 18 inches in the row.

The fall bearing Strawberries do best north of central Iowa, where if proper care is given and conditions are favorable, wonderful results can be had from the Progressive variety. They should be planted early in the spring on good, rich ground and a new patch planted each year.

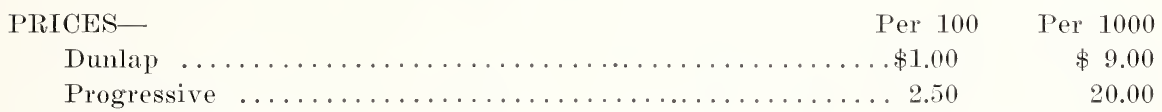

\section{ASPARAGUS}

This is one of the first ready-to-use and most wholesome of the spring vegetables. Plant it along the fence and plant it by the hundred rather than by the dozen.

PRICES-
Two-year plants $\ldots \ldots \ldots \ldots \ldots \ldots \ldots \ldots \ldots \ldots \$ 0.40$

\section{RHUBARB}

Rhubarb, like Asparagus, should be planted where it need not be disturbed and will produce a great lot of wholesome food with the minimum amount of work. Heavy clumps of it may be forced in the cellar in winter if they are dug in the fall and allowed to freeze hard before taking in.

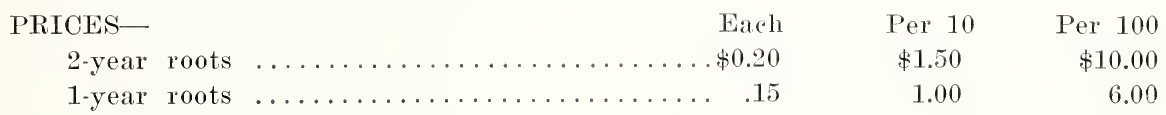

\section{EVERGREENS}

All the evergreens we offer have been transplanted two or more times. They are always dug fresh as sent out. If the buyer comes to the Nursery after them, they can be lifted directly from the row to his truck and have a minimum of exposure. If the roots of evergreens ever become thoroughly dry they cannot be revived as other trees can. Failure in transplanting them is largely due to allowing them to become dry while planting, to not packing good, mellow, moist soil very firmly around the roots, or to not properly conserving moisture about them through the summer by frequent shallow cultivation and by mulching.

SPACING. Plant Pines or Spruces 7 to 8 feet apart for single row windbreaks, and 10 to 12 feet apart for double rows. For hedges plant 18 to 24 inches apart, depending on size.

SOILs. Plant Pines on dry or well drained soil. The Bull Pine will do well on very gravelly soil. In places where it is quite wet at times Spruce will be better, and in very wet places Arborvitae is the best. 


\section{EVERGREENS FOR WINDBREAKS AND HEDGES}

Prices in this section do not include Ball and Burlap; if wanted that way, the expense of it must be added.

ARBORVITAE-American

\begin{tabular}{|c|c|c|c|}
\hline Size & Each & Per 10 & Per 100 \\
\hline 5 to $6 \mathrm{ft}$. & $\$ 1.50$ & $\$ 14.00$ & $\$ 125.00$ \\
\hline 4 to $5 \mathrm{ft}$. & 1.25 & 12.00 & 100.00 \\
\hline 3 to $4 \mathrm{ft}$. & 1.00 & 9.00 & 75.0 \\
\hline 2 to $3 \mathrm{ft}$. & .75 & 7.00 & 60. \\
\hline 12 to $15 \mathrm{in.}$ & .40 & 3.50 & 30.00 \\
\hline to $6 \mathrm{ft}$. & $\$ 0.90$ & $\$ 8.50$ & $\$ 80.00$ \\
\hline 4 to $5 \mathrm{ft}$. & .75 & 7.00 & 65.0 \\
\hline to $4 \mathrm{ft}$. & .65 & 6.00 & 55 \\
\hline to $3 \mathrm{ft}$. & .55 & 5.00 & \\
\hline to 24 & .45 & 4.00 & \\
\hline
\end{tabular}

A native of the north, preferring a moist soil. All large sizes are three times transplanted.

\section{PINE-Bull (Pinus Ponderosa Western}

Yellow Pine) $\ldots \ldots \ldots \ldots \ldots \ldots \ldots \ldots \ldots \ldots \ldots \ldots \ldots$ A native of the Black Hills, with very long needles and thick, stout branches, which are not broken by heavy sleet or serere storms. Extremely hardy and drouth-resistant.

\begin{tabular}{|c|c|c|c|c|}
\hline $\begin{array}{l}\text { INE-Scotch } \ldots \ldots \ldots \ldots \ldots \ldots \ldots \ldots \ldots \\
\text { Native to Northern Europe. }\end{array}$ & $\begin{array}{l}5 \text { to } 6 \mathrm{ft} \\
\pm \text { to } 5 \mathrm{ft} \\
3 \text { to } 4 \mathrm{ft}\end{array}$ & $\begin{array}{r}\$ 1.25 \\
1.00 \\
.90\end{array}$ & $\begin{array}{r}\$ 12.00 \\
9.00 \\
8.00\end{array}$ & \\
\hline $\begin{array}{l}\text { INE-White } \ldots \ldots \ldots \ldots \ldots \ldots \ldots \ldots \ldots \ldots \ldots \\
\text { One of Iowa's few native conifers. }\end{array}$ & 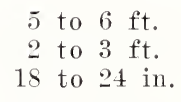 & $\begin{array}{r}\$ 1.25 \\
.75 \\
.60\end{array}$ & $\begin{array}{r}\$ 12.00 \\
7.00 \\
5.50\end{array}$ & $\begin{array}{r}\$ 60.00 \\
50.00\end{array}$ \\
\hline $\begin{array}{l}\text { SED CEDAR ................................. } \\
\text { because of the Cedar Apple rust, other- } \\
\text { wise very desirable. }\end{array}$ & 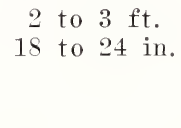 & $\$ 0.90$ & $\$ \begin{array}{l}8.00 \\
6.00\end{array}$ & \\
\hline $\begin{array}{l}\text { SPRUCE-Norway ......................... } \\
\text { Native to northern Europe. Nost } \\
\text { grown and recommended by Nursery- } \\
\text { men because it is the easiest to grow. }\end{array}$ & 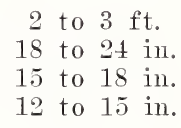 & $\begin{array}{r}\$ 0.75 \\
.60 \\
.50 \\
.40\end{array}$ & $\begin{array}{l}7.00 \\
5.50 \\
4.50 \\
3.50\end{array}$ & $\begin{array}{r}\$ 60.00 \\
50.00 \\
40.00 \\
30.00\end{array}$ \\
\hline $\begin{array}{l}\text { PRUCE-White ..................... } \\
\text { Native to northeastern America, and } \\
\text { very desirable. }\end{array}$ & 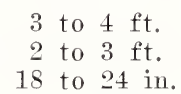 & $\begin{array}{r}\$ 1.25 \\
1.00 \\
.75\end{array}$ & $\begin{array}{r}\$ 12.00 \\
8.50 \\
7.00\end{array}$ & \\
\hline
\end{tabular}

\section{SPECIMEN EVERGREENS-For Landscape Planting}

The following are well developed trees which have been several times transplanted and are dug with a solid ball of earth securely burlapped and bound. They are much heavier to handle, but easier to plant and more certain to grow. In planting do not remove the burlap. After the tree is in place and the hole partly filled to hold it, cut the burlap loose around the top and pour in plenty of water. Large trees over 8 feet should be ordered before hard freezing so they can be moved with frozen ball of dirt in the winter.

\begin{tabular}{|c|c|c|c|}
\hline ARBORVITAE-American $\ldots \ldots \ldots \ldots$ & $\begin{aligned} & \text { Size } \\
& 15 \text { to } 18 \mathrm{in} . \\
& 18 \text { to } 24 \mathrm{in} . \\
& 2 \text { to } 3 \mathrm{ft} . \\
& 3 \text { to } 4 \mathrm{ft} . \\
& 4 \text { to } 5 \mathrm{ft} . \\
& 5 \text { to } 6 \mathrm{ft} .\end{aligned}$ & $\begin{array}{r}\text { Each } \\
\$ 0.75 \\
1.00 \\
1.50 \\
2.00 \\
2.50 \\
3.00\end{array}$ & $\begin{array}{r}\text { Per } 10 \\
\$ 7.00 \\
9.00 \\
12.00 \\
17.50 \\
20.00 \\
25.00\end{array}$ \\
\hline $\begin{array}{l}\text { Globe } \ldots \ldots \ldots \text {. . . . . . . . . . . . . . . } \\
\text { globes without trimming. }\end{array}$ & $\begin{aligned} & 10 \text { to } 12 \mathrm{in} . \\
& 18 \text { to } 24 \mathrm{in} . \\
& 2 \text { to } 21 / 2 \mathrm{ft} . \\
& 3 \text { to } 4 \mathrm{ft} \text {. }\end{aligned}$ & $\begin{array}{r}\$ 1.00 \\
3.00 \\
4.00 \\
6.00\end{array}$ & \\
\hline
\end{tabular}


SPECIMEN EVERGREENS-Continued

\begin{tabular}{|c|c|c|c|}
\hline Hovey's Golden ................ & $\begin{array}{l}\text { Size } \\
15 \text { to } 18 \mathrm{in} . \\
18 \text { to } 24 \mathrm{in} .\end{array}$ & $\begin{array}{r}\text { Each } \\
\$ 1.50 \\
2.00\end{array}$ & $\begin{array}{r}\operatorname{Per} 10 \\
\$ 12.50 \\
17.50\end{array}$ \\
\hline Pyramidal $\ldots \ldots \ldots \ldots \ldots \ldots \ldots \ldots$ & $\begin{array}{l}12 \text { to } 15 \mathrm{in} . \\
15 \text { to } 18 \mathrm{in} . \\
18 \text { to } 24 \mathrm{in} . \\
2 \text { to } 21 / 2 \mathrm{ft} . \\
21 / 2 \text { to } 3 \mathrm{ft} . \\
3 \text { to } 31 / 2 \mathrm{ft} .\end{array}$ & $\begin{array}{r}\$ 1.00 \\
1.50 \\
2.25 \\
3.00 \\
4.00 \\
5.00\end{array}$ & \\
\hline $\begin{array}{l}\text { Siberian } \ldots \ldots \ldots \ldots \ldots \ldots \\
\text { The hardiest of all the arborvitae, } \\
\text { very compact, conical in form and } \\
\text { with dense dark green foliage. }\end{array}$ & $\begin{array}{l}18 \text { to } 24 \mathrm{in} . \\
2 \text { to } 21 / 2 \mathrm{ft} \text {. } \\
21 / 2 \text { to } 3 \mathrm{ft} \text {. } \\
3 \text { to } 31 / 2 \mathrm{ft} \text {. } \\
31 / 2 \text { to } 4 \mathrm{ft} \text {. } \\
6 \text { to } 7 \mathrm{ft} .\end{array}$ & $\begin{array}{r}\$ 2.50 \\
3.00 \\
4.00 \\
5.00 \\
6.00 \\
12.00\end{array}$ & $\begin{array}{r}\$ 24.00 \\
28.00 \\
35.00 \\
40.00 \\
50.00\end{array}$ \\
\hline $\begin{array}{l}\text { IR_Balsam ............................. } \\
\text { A native of Iowa and Northeast. It } \\
\text { should have moist soil. The leaves } \\
\text { and branches are delightfully frag- }\end{array}$ & $\begin{array}{l}3 \text { to } 4 \mathrm{ft} . \\
4 \text { to } 5 \\
5 \text { to } 6 \\
6 \text { to } 7 \mathrm{ft} .\end{array}$ & $\begin{array}{r}\$ 1.50 \\
2.00 \\
2.50 \\
3.00\end{array}$ & \\
\hline
\end{tabular}

rant.
Concolor .................... 15 to 18 in. $\$ 3.00$
18 to 24 in. 4.00
2 to $3 \mathrm{ft}$. $\quad 5.00$

Larger sizes quoted on application.
Douglas ................. 2 to $21 / 2 \mathrm{ft}$. $\$ 2.00$
Also known as Douglas Spruce. $\quad 21 / 2$ to $3 \mathrm{ft} \quad 3.00$
3 to $4 \mathrm{ft}$. 4.00
4 to 5 ft. $\quad 5.00$

HEMIOCK

18 to $24 \mathrm{in.} \$ 2.50$

$\begin{array}{llll}\text { Native to northeastern United States. } & 2 \text { to } 21 / 2 \mathrm{ft} & 3.50 \\ \text { A slow growing, graceful tree with } & 21 / 2 \text { to } 3 \mathrm{ft} & 4.50\end{array}$

short, flat needles, bright green above; 3 to $31 / 2 \mathrm{ft}$. $\quad 6.00$

silvery beneath.

$31 / 2$ to $4 \mathrm{ft}$. $\quad 7.00$

\pm to $5 \mathrm{ft}$. 8.00

5 to 6 ft. $\quad 9.00$

6 to $7 \mathrm{ft} . \quad 10.00$

JUNIPER-Pfitzer's ............ 12 to 15 in. spread $\$ 2.00$

A variety of the Chinese Juniper. The 15 to $18 \mathrm{in}$. spread 2.50

foliage is bluish green and the is to $24 \mathrm{in}$. spread 4.00

branches grow out horizontally from 2 to $3 \mathrm{ft}$. spread 5.00

the stem, which gives the tree an in-

dividuality of its own.

\begin{tabular}{|c|c|c|}
\hline Savin $\ldots \ldots \ldots \ldots \ldots \ldots \ldots$ & 9 to 12 in. & $\$ 1.50$ \\
\hline A bushy little tree with semi-erect & 12 to $15 \mathrm{in}$. & 2.00 \\
\hline $\begin{array}{l}\text { branches and clear green foliage. It } \\
\text { is excellent for foundation plant- } \\
\text { ings and in rockeries or dry sunny } \\
\text { places. }\end{array}$ & 15 to $18 \mathrm{in}$ & 3.00 \\
\hline Virginiana (Red Cedar) ............ & $\begin{array}{l}3 \text { to } 4 \\
4 \text { to } 5 \\
5 \text { ft. } \\
5 \text { to } 6 \\
6 \text { to } 7 \\
7 \text { to } 8 \text { ft. }\end{array}$ & $\begin{array}{r}\$ 3.00 \\
4.00 \\
5.00 \\
6.00 \\
8.00\end{array}$ \\
\hline
\end{tabular}




\section{SPECIMEN EVERGREENS-Continued}

\begin{tabular}{|c|c|c|c|}
\hline $\begin{array}{l}\text { LARCH-European } \ldots \ldots \ldots \ldots \ldots \ldots \ldots \ldots \\
\quad \text { A conifer, but not an evergreen. }\end{array}$ & $\begin{array}{l}\text { size } \\
3 \text { to } \pm \mathrm{ft} \\
\pm \text { to } 5 \mathrm{ft} \\
5 \text { to } 6 \mathrm{ft}\end{array}$ & $\begin{array}{l}\text { Fach } \\
\$ 2.00 \\
2.50 \\
3.50\end{array}$ & Per 10 \\
\hline $\begin{array}{l}\text { PINE-Bull ........................... } \\
\quad \text { Larger sizes quoted upon application. }\end{array}$ & 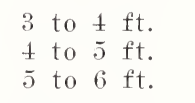 & $\begin{array}{r}\$ 2.50 \\
3.50 \\
+.50\end{array}$ & $\begin{array}{r}\$ 22.00 \\
32.00 \\
+0.00\end{array}$ \\
\hline $\begin{array}{l}\text { Mugho ............................ } \\
\text { Dwarf mountain pine. This makes } \\
\text { a compact dome-shaped bush broar- } \\
\text { er than high. sizes apply to width } \\
\text { rather than height. }\end{array}$ & $\begin{array}{l}12 \text { to } 15 \mathrm{in} . \\
15 \text { to } 18 \mathrm{in} . \\
18 \text { to } 24 \mathrm{in} .\end{array}$ & $\begin{array}{r}\$ 3.00 \\
\quad \pm .00 \\
5.00\end{array}$ & \\
\hline $\begin{array}{l}\text { Red ..................................... } \\
\text { Needles long and soft and a very } \\
\text { pretty green. One of the most beau- } \\
\text { beautiful pines. }\end{array}$ & $\begin{array}{l} \pm \text { to } \overline{\mathrm{j}} \mathrm{ft} . \\
5 \text { to } 6 \mathrm{ft}\end{array}$ & $\begin{array}{r}\$ 3.00 \\
\pm .00\end{array}$ & $\begin{array}{r}\$ 28.00 \\
35.00\end{array}$ \\
\hline $\operatorname{Scotch} \ldots \ldots \ldots \ldots \ldots \ldots \ldots$ & 3 to $4 \mathrm{ft}$. & $\$ 3.00$ & $\$ 25.00$ \\
\hline $\begin{array}{l}\text { Whito ..... } \\
\text { Sizes up to } 10 \text { ft. quoted on appli- } \\
\text { cation. }\end{array}$ & $\begin{array}{l}3 \text { to } \pm \mathrm{ft} \\
\pm \text { to } 5 \mathrm{ft} \\
5 \text { to } 6 \mathrm{ft} \\
\text { size }\end{array}$ & $\begin{array}{r}+2.50 \\
3.50 \\
\pm .50 \\
\text { Each }\end{array}$ & $\begin{array}{r}\$ 22.00 \\
32.00 \\
10.00 \\
\text { Per } 10\end{array}$ \\
\hline $\begin{array}{l}\text { SPRUCE_-Black Hills ................ } \\
\text { A native of the Black Hills. It does } \\
\text { very well over a wide range and } \\
\text { makes the finest specimens of all } \\
\text { spruce mless it be the Colorado Blue. }\end{array}$ & $\begin{array}{l}15 \text { to } 18 \mathrm{in} . \\
18 \text { to } 24 \mathrm{in} . \\
2 \text { to } 21 / 2 \mathrm{ft} \text {. } \\
21 / 2 \text { to } 3 \mathrm{ft} \text {. } \\
3 \text { to } \pm \mathrm{ft} . \\
4 \text { to } 5 \mathrm{ft} . \\
5 \text { to } 6 \mathrm{ft} . \\
6 \text { to } 7 \mathrm{ft} .\end{array}$ & $\begin{array}{l}\$ 1.50 \\
2.00 \\
2.50 \\
3.00 \\
+.00 \\
5.00 \\
6.50 \\
8.00\end{array}$ & $\begin{array}{l}\$ 12.50 \\
17.50 \\
22.50 \\
27.50 \\
37.50 \\
45.00 \\
60.00 \\
75.00\end{array}$ \\
\hline
\end{tabular}

\section{Colorado Blue}

A native of Colorado. It varies from clear green to glistening silvery blue. They are slow growing and very compact, making the finest lawn specimens.

\section{Selected Blue Specimens or}

Shiners

$$
\begin{aligned}
& 15 \text { to } 18 \mathrm{in} . \\
& 18 \text { to } 24 \mathrm{in} . \\
& 2 \text { to } 21 / 2 \mathrm{ft} . \\
& 21 / 2 \text { to } 3 \mathrm{ft} \text {. } \\
& 3 \text { to } 4 \mathrm{ft} \text {. } \\
& 4 \text { to } 5 \mathrm{ft} \text {. }
\end{aligned}
$$

Green Specimens

$$
\begin{aligned}
& 18 \text { to } 24 \mathrm{in} \text {. } \\
& 2 \text { to } 21 / 2 \mathrm{ft} \text {. } \\
& 21 / 2 \text { to } 3 \mathrm{ft} \text {. } \\
& 3 \text { to } \pm \mathrm{ft} \text {. } \\
& \pm \text { to } 5 \mathrm{ft} . \\
& 5 \text { to } 6 \mathrm{ft} \text {. }
\end{aligned}
$$

Norway

$$
\begin{aligned}
& 3 \text { to } \pm \mathrm{ft} . \\
& \pm \text { to } 5 \mathrm{ft} \text {. }
\end{aligned}
$$

Sizes up to 18 feet quoted on application.

$\$ 2.50$ 
SPECIMEN EVERGREENS-Continued

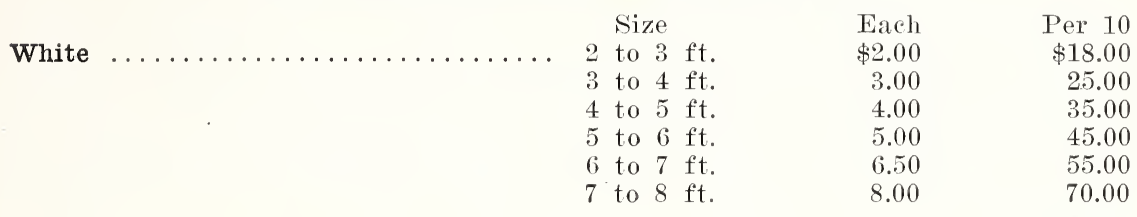

\section{SHADE AND ORNAMENTAL TREES}

We have numerous trees, which are too large for boxing and shipping, which we will quote on application. They consist of American Elm up to 6 inches in diameter, Burr Oak up to 4 inches, Ash up to $2 \frac{1}{2}$ inches, and Maples up to $4 \frac{1}{2}$ inches.

\begin{tabular}{|c|c|c|c|}
\hline AILANTHUS (Tree of Heaven) & $\begin{array}{l}\text { Size } \\
5 \text { to } 6 \mathrm{ft} \\
4 \text { to } 5 \mathrm{ft}\end{array}$ & $\begin{array}{r}\text { Each } \\
\$ 1.50 \\
1.00\end{array}$ & $\begin{array}{r}\text { Per } 10 \\
\$ 12.00 \\
9.00\end{array}$ \\
\hline ASH-American $\ldots \ldots \ldots \ldots \ldots \ldots \ldots \ldots$ & 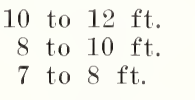 & $\begin{array}{l}2.00 \\
1.50 \\
1.00\end{array}$ & $\begin{array}{l}18.00 \\
14.00 \\
10.00\end{array}$ \\
\hline BIRCH_European White $\ldots \ldots \ldots \ldots \ldots$ & $\begin{array}{l}6 \text { to } 8 \mathrm{ft} . \\
5 \text { to } 6 \mathrm{ft} .\end{array}$ & $\begin{array}{l}2.50 \\
1.75\end{array}$ & $\begin{array}{l}22.00 \\
16.00\end{array}$ \\
\hline CATALPA—Speciosa $\ldots \ldots \ldots \ldots \ldots \ldots$ & $\begin{array}{l}6 \text { to } 8 \mathrm{ft} . \\
5 \text { to } 6 \mathrm{ft} .\end{array}$ & $\begin{array}{r}1.25 \\
.90\end{array}$ & $\begin{array}{r}10.00 \\
7.50\end{array}$ \\
\hline CRAB_-Bechtel's Double Flowering $\ldots \ldots$ & $\begin{array}{r}4 \text { to } 5 \mathrm{ft} . \\
3 \text { to } 4 \mathrm{ft} . \\
2 \text { to } 3 \mathrm{ft} \\
18 \text { to } 24 \mathrm{in} .\end{array}$ & $\begin{array}{r}2.50 \\
1.75 \\
1.25 \\
.75\end{array}$ & $\begin{array}{r}22.00 \\
15.00 \\
12.00 \\
7.00\end{array}$ \\
\hline Hoppa-Hansen's Red Siberian ...... & 3 to $4 \mathrm{ft}$. & 1.00 & \\
\hline Niedzwetzkyana, Redvein .......... & $\begin{array}{l}4 \text { to } 5 \mathrm{ft} . \\
3 \text { to } 4 \mathrm{ft} .\end{array}$ & $\begin{array}{r}1.00 \\
.75\end{array}$ & $\begin{array}{l}9.00 \\
7.00\end{array}$ \\
\hline ELM-American White ....... & $\begin{array}{r}10 \text { to } 12 \mathrm{ft} . \\
8 \text { to } 10 \mathrm{ft} . \\
7 \text { to } 8 \mathrm{ft} . \\
6 \text { to } 7 \mathrm{ft} . \\
5 \text { to } 6 \\
\end{array}$ & $\begin{array}{r}2.00 \\
1.50 \\
1.00 \\
.90 \\
.60\end{array}$ & $\begin{array}{r}17.50 \\
12.50 \\
8.50 \\
7.50 \\
5.00\end{array}$ \\
\hline Moline . . . . . . . . . . . & $\begin{array}{l}8 \text { to } 10 \mathrm{ft} \text {. } \\
6 \text { to } 8 \mathrm{ft} \text {. }\end{array}$ & $\begin{array}{l}3.00 \\
2.50\end{array}$ & \\
\hline Weeping $\ldots \ldots \ldots \ldots \ldots \ldots \ldots \ldots$ & 2-year heads & 3.00 & \\
\hline GINKGO (Maiden Hair Tree) .. & $\begin{array}{l}3 \text { to } 4 \mathrm{ft} . \\
4 \text { to } 5 \mathrm{ft} .\end{array}$ & $\begin{array}{l}1.25 \\
1.50\end{array}$ & \\
\hline HACKBERRY & $\begin{array}{l}8 \text { to } 10 \mathrm{ft} . \\
7 \text { to } 8 \mathrm{ft} . \\
6 \text { to } 7 \mathrm{ft} . \\
5 \text { to } 6 \mathrm{ft}\end{array}$ & $\begin{array}{l}2.50 \\
2.00 \\
1.50 \\
1.25\end{array}$ & $\begin{array}{l}22.00 \\
18.00 \\
14.00 \\
10.00\end{array}$ \\
\hline HICKORY_-Shagbark $\ldots \ldots \ldots \ldots \ldots \ldots$ & $\begin{array}{l}5 \text { to } 6 \\
4 \text { to } 5 \mathrm{ft}\end{array}$ & $\begin{array}{l}3.00 \\
2.50\end{array}$ & $\begin{array}{l}25.00 \\
22.00\end{array}$ \\
\hline HORSE CHESTNUT & $\begin{array}{l}5 \text { to } 6 \mathrm{ft} . \\
4 \text { to } 5 \mathrm{ft} \text {. }\end{array}$ & $\begin{array}{l}2.50 \\
2.00\end{array}$ & $\begin{array}{l}24.00 \\
18.00\end{array}$ \\
\hline
\end{tabular}


SHADE AND ORNAMENTAI TREES-Continued

\begin{tabular}{|c|c|c|c|}
\hline KENTUCKY COFFEE TREE .......... & \begin{tabular}{l}
\multicolumn{3}{c}{ Size } \\
3 to $4 \mathrm{ft}$. \\
4 to $5 \mathrm{ft}$.
\end{tabular} & $\begin{array}{r}\text { Each } \\
\$ 1.00 \\
1.50\end{array}$ & Per 10 \\
\hline LINDEN-American $\ldots \ldots \ldots \ldots \ldots \ldots$ & $\begin{array}{l}8 \text { to } 10 \mathrm{ft.} \\
6 \text { to } 8 \mathrm{ft} . \\
5 \text { to } 6 \mathrm{ft} \text {. }\end{array}$ & $\begin{array}{l}2.50 \\
2.00 \\
1.50\end{array}$ & $\begin{array}{r}\$ 22.00 \\
18.00 \\
12.50\end{array}$ \\
\hline LOCUST-Honey, Thornless . . & 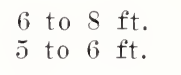 & $\begin{array}{l}1.25 \\
.75\end{array}$ & $\begin{array}{r}10.00 \\
7.00\end{array}$ \\
\hline $\begin{array}{l}\text { MAPLE-Hard or Sugar ................ } \\
\text { Larger sizes quoted on application. }\end{array}$ & $\begin{array}{l}8 \text { to } 10 \mathrm{ft} . \\
7 \text { to } 8 \mathrm{ft} . \\
6 \text { to } 7 \\
5 \text { to } 6 \mathrm{ft} .\end{array}$ & $\begin{array}{l}3.00 \\
2.50 \\
2.00 \\
1.50\end{array}$ & $\begin{array}{l}28.00 \\
22.00 \\
17.50 \\
14.00\end{array}$ \\
\hline$\ldots \ldots \ldots \ldots \ldots \ldots$ & $\begin{array}{l}8 \text { to } 10 \mathrm{ft} . \\
6 \text { to } 8 \mathrm{ft} . \\
5 \text { to } 6 \mathrm{ft} .\end{array}$ & $\begin{array}{l}4.00 \\
3.00 \\
2.25\end{array}$ & $\begin{array}{l}37.50 \\
28.00 \\
20.00\end{array}$ \\
\hline Tartarian (Ginala) ............... & $\begin{array}{l}4 \text { to } 5 \mathrm{ft} . \\
3 \text { to } 4 \mathrm{ft} . \\
2 \text { to } 3 \mathrm{ft} .\end{array}$ & $\begin{array}{l}2.00 \\
1.50 \\
1.00\end{array}$ & $\begin{array}{r}18.00 \\
14.00 \\
9.00\end{array}$ \\
\hline Schwedler's Purple Leaved Maple ..... & 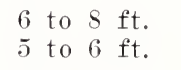 & $\begin{array}{l}4.00 \\
3.50\end{array}$ & \\
\hline Weir's Cut Leaved ................ & $\begin{array}{l}5 \text { to } 6 \mathrm{ft} . \\
\pm \text { to } 5 \mathrm{ft} .\end{array}$ & $\begin{array}{l}1.50 \\
1.00\end{array}$ & \\
\hline MAY DAY TREE $\ldots \ldots \ldots \ldots \ldots \ldots$ & 5 to $6 \mathrm{ft}$. & 1.50 & \\
\hline MOUNTAIN ASH-European $\ldots \ldots \ldots \ldots$ & 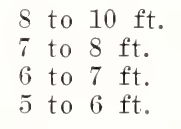 & $\begin{array}{l}3.00 \\
2.50 \\
2.20 \\
1.75\end{array}$ & $\begin{array}{l}28.00 \\
24.00 \\
20.00 \\
16.00\end{array}$ \\
\hline MULBERRY_Russian $\ldots \ldots \ldots \ldots \ldots$ & $\begin{array}{l}7 \text { to } 8 \mathrm{ft} . \\
6 \text { to } 7 \mathrm{ft} . \\
5 \text { to } 6 \\
4 \text { to } 5 \mathrm{ft} .\end{array}$ & $\begin{array}{l}.90 \\
.75 \\
.60 \\
.50\end{array}$ & $\begin{array}{l}8.50 \\
7.00 \\
5.00 \\
4.00\end{array}$ \\
\hline weeping $\ldots \ldots \ldots \ldots \ldots \ldots \ldots \ldots$ & -year & 5.00 & \\
\hline OAK-Burr . . & $\begin{array}{r}10 \text { to } 12 \mathrm{ft} \\
8 \text { to } 10 \mathrm{ft} . \\
7 \text { to } 8 \mathrm{ft} . \\
6 \text { to } 7 \mathrm{ft} . \\
5 \text { to } 6 \mathrm{ft} \text {. }\end{array}$ & $\begin{array}{l}5.00 \\
4.00 \\
3.00 \\
2.50 \\
2.00\end{array}$ & $\begin{array}{l}45.00 \\
36.00 \\
28.00 \\
24.00 \\
18.00\end{array}$ \\
\hline Pin .. & $\begin{array}{l}8 \text { to } 10 \mathrm{ft} . \\
7 \text { to } 8 \mathrm{ft} . \\
6 \text { to } 7 \mathrm{ft} . \\
5 \text { to } 6 \mathrm{ft} .\end{array}$ & $\begin{array}{l}5.00 \\
4.00 \\
3.00 \\
2.50\end{array}$ & $\begin{array}{l}36.00 \\
28.00 \\
24.00\end{array}$ \\
\hline $\begin{array}{l}\text { OLIVE-Russian } \ldots . . . \ldots \ldots \ldots \ldots \ldots \ldots \\
\quad \text { (See under Hedging also). }\end{array}$ & $\begin{array}{l}6 \text { to } 7 \mathrm{ft} . \\
5 \text { to } 6 \mathrm{ft} . \\
4 \text { to } 5 \mathrm{ft} .\end{array}$ & $\begin{array}{r}1.50 \\
1.00 \\
.75\end{array}$ & $\begin{array}{r}14.00 \\
9.50 \\
7.00\end{array}$ \\
\hline $\begin{array}{l}\text { POPLAR_Carolina ................... } \\
\text { (Smaller sizes under Forest Tree Seed- } \\
\text { lings). }\end{array}$ & $\begin{array}{l}10 \text { to } 12 \mathrm{ft} . \\
8 \text { to } 10 \mathrm{ft} . \\
6 \text { to } 8 \mathrm{ft} . \\
5 \text { to } 6 \mathrm{ft} \text {. }\end{array}$ & $\begin{array}{r}1.00 \\
.75 \\
.50 \\
.40\end{array}$ & $\begin{array}{l}9.00 \\
6.00 \\
4.00 \\
2.50\end{array}$ \\
\hline
\end{tabular}


SHADE AND ORNAMENTAL TREES-Continued

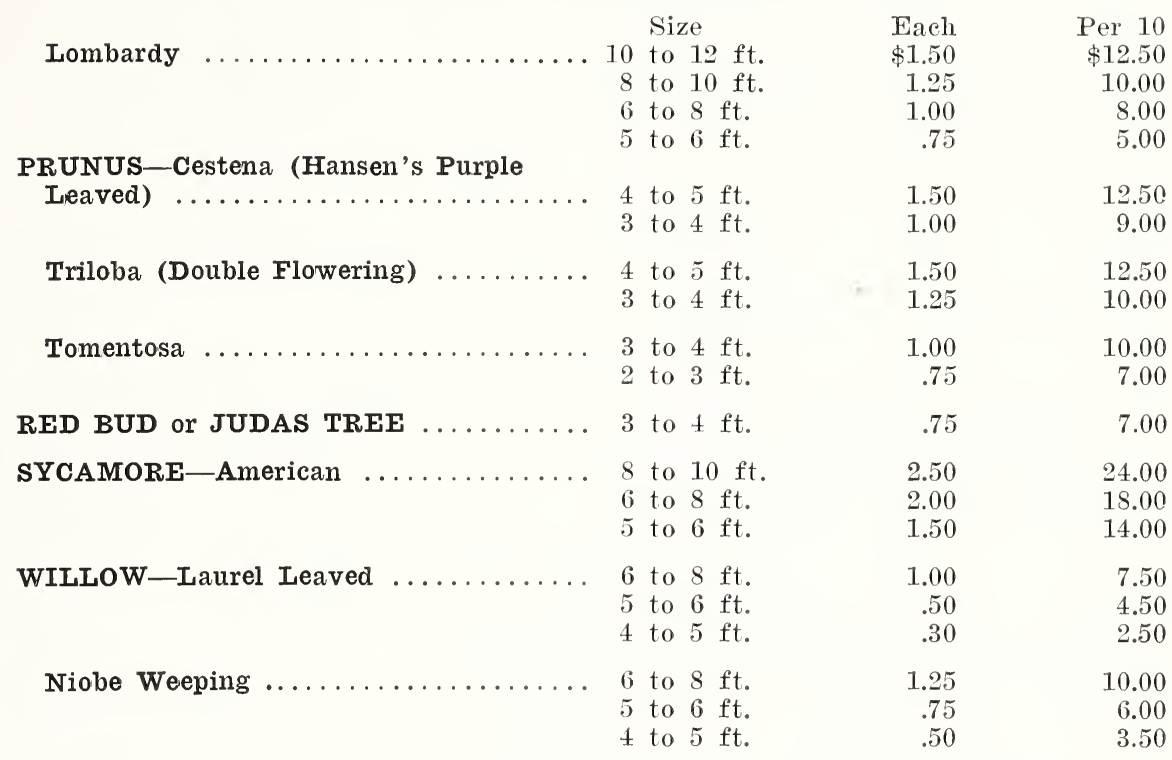

\section{SHRUBS}

\begin{tabular}{|c|c|c|c|}
\hline & Size & Each & Per 10 \\
\hline ALMONDS-Flowering & 3 to $4 \mathrm{ft}$. & $\$ 1.50$ & $\$ 12.50$ \\
\hline On Plum roots; pink and white. & 2 to $3 \mathrm{ft}$ & 1.20 & 10.00 \\
\hline & 18 to $24 \mathrm{in}$. & .90 & 8.00 \\
\hline ALTHEAS-Assorted $\ldots \ldots \ldots \ldots \ldots \ldots$ & 3 to $4 \mathrm{ft}$. & .75 & 7.00 \\
\hline & 2 to $3 \mathrm{ft}$. & .60 & 5.00 \\
\hline ARALIA PENTAPHYLLA. & 2 to $3 \mathrm{ft}$. & .50 & 4.50 \\
\hline . & 18 to $24 \mathrm{in}$. & .40 & 3.50 \\
\hline BARBERRY THUNBERGII & & & \\
\hline $\begin{array}{l}\text { See under Hedge Plants. } \\
\text { BUTTERFLY BUSH-\#1 Plants } \ldots . . . .\end{array}$ & & .50 & 4.00 \\
\hline BUTTON BUSH (Cephalanthus & & & \\
\hline Occidentalis) $\ldots \ldots \ldots \ldots \ldots$ & 2 to $3 \mathrm{ft}$. & .60 & 5.00 \\
\hline & 18 to 24 in. & .50 & 4.00 \\
\hline CARAGANA (Siberian Pea Tree). & 4 to $5 \mathrm{ft}$. & .60 & 5.00 \\
\hline & 3 to $4 \mathrm{ft}$. & .50 & 4.00 \\
\hline & 2 to $3 \mathrm{ft}$. & .40 & 3.00 \\
\hline & 18 to 24 in. & .30 & 2.00 \\
\hline CORAL BERRY (Indian Currant or & & & \\
\hline Red Snowberry) $\ldots \ldots \ldots \ldots \ldots \ldots$ & 3 to $4 \mathrm{ft}$. & .50 & 4.00 \\
\hline & 2 to $3 \mathrm{ft}$. & .40 & 3.00 \\
\hline & 18 to $24 \mathrm{in.}$ & .30 & 2.50 \\
\hline CORNUS (Dogwood & & & \\
\hline Alternifolia, very shade enduring...... & 2 to $3 \mathrm{ft}$ & .50 & 4.50 \\
\hline & 18 to 24 in. & .40 & 3.50 \\
\hline
\end{tabular}




\section{SHRUBS-Continued}

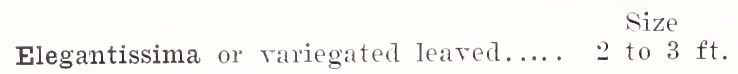

Each

$\$ 0.75$

Florida (large white flowering)...... 2 to $3 \mathrm{ft}$.

15 to $24 \mathrm{in}$.

Alba siberica (red twigged) ....... $t$ to $5 \mathrm{ft}$.

3 to $\pm \mathrm{ft}$.

2 to $3 \mathrm{ft}$.

18 to $24 \mathrm{in}$.

Stolonifera Lutea (yellow twigged).... 3 to $4 \mathrm{ft}$.

2 to $3 \mathrm{ft}$.

18 to $24 \mathrm{in}$.

COTONEASTER, Acutifolia

3 to $4 \mathrm{ft}$.

2 to $3 \mathrm{ft}$.

CRANBERRY HIGHBUSH (Viburnum

Opulis)

3 to $4 \mathrm{ft}$.

2 to $3 \mathrm{ft}$.

18 to $24 \mathrm{in}$.

1:. to $18 \mathrm{in}$.

CURRANTS-Yellow flowering........ 3 to $4 \mathrm{ft}$.

2 to $3 \mathrm{ft}$.

Alpine ..................... Is to $24 \mathrm{in}$.

15 to $18 \mathrm{in}$.

12 to $15 \mathrm{in}$.

DESMODIUM Pendulifolium ........ $\neq 1$ size

DEUTZIA LEMOINEI ............ 18 to $24 \mathrm{in}$.

12 to $18 \mathrm{in}$.

ELDER-Cut Leaved ............ 3 to $4 \mathrm{ft}$.

2 to 3 ft.

18 to $24 \mathrm{in}$.

Golden

3 to $4 \mathrm{ft}$.

2 to $3 \mathrm{ft}$.

18 to $24 \mathrm{in}$.

Red Berried .................. 2 to $3 \mathrm{ft}$.

ENOYNYMUS ALATUS (Winged Wahoo) 6 to $7 \mathrm{ft}$.

FORSYTHIA INTERMEDIA (Yellow

Bells)

18 to 24 ill.

4 to $5 \mathrm{ft}$.

3 to $t \mathrm{ft}$.

2 to $3 \mathrm{ft}$.

18 to $24 \mathrm{in}$.

HONEYSUCKLE-Bella Albida ....... 3 to $\pm \mathrm{ft}$.

2 to $3 \mathrm{ft}$.

18 to 24 in.

Morrow's

3 to $4 \mathrm{ft}$.

2 to $3 \mathrm{ft}$.

18 to $24 \mathrm{in}$.

Rupecht's

3 to $4 \mathrm{ft}$.

2 to $3 \mathrm{ft}$.

18 to $24 \mathrm{in}$.
.75

.60

.60

.50

.40

.30

.75

.50

.40

.75

.60

1.00

.80

.65

.40

.60

.50

.75

.60

.50

.75

.60

.45

.60

.50

. \pm 0

.75

.60

.45

.75

3.50

.75

.60

.50

.40

.30

.60

.50

.40

.60

.50

.40

.60

.50

.40
Per 10

$\$ 7.00$

7.00

5.00

5.00

4.00

3.00

2.00

6.00

4.00

3.00

7.00

5.00

9.00

7.00

6.00

3.00

5.00

4.00

7.00

5.00

$\pm .00$

7.00

5.00

4.00

5.00

4.00

3.00

7.00

5.00

4.00

7.00

7.00

5.00

4.00

3.00

2.00

5.00

4.00

3.00

5.00

4.00

3.00

5.00

4.00

3.00 
SHRUBS-Continued.

Size
Tartarian-Pink or white $\ldots \ldots \ldots \ldots$
4 to $5 \mathrm{ft}$.
3 to $4 \mathrm{ft}$.
2 to $3 \mathrm{ft}$.
18 to $24 \mathrm{in}$.

$\begin{array}{rr}\text { Each } & \text { Per } 10 \\ \$ 0.75 & \$ 6.00 \\ .60 & 5.00 \\ .50 & 4.00 \\ .40 & .300 \\ & \\ .75 & 7.00 \\ .60 & 5.00 \\ .45 & 4.00\end{array}$

Paniculata Grandiflora (Hardy

Arborescens (Hills of Snow) ....... 2 to $3 \mathrm{ft}$. 18 to $24 \mathrm{in}$.

Hydrangea)

Bush Form ................ 2 to $3 \mathrm{ft}$.

Tree Form ................... 4 to $5 \mathrm{ft}$.

LILACS . . . . . . . . . . . 3 to $4 \mathrm{ft}$.

Common Purple and Common White. 2 to $3 \mathrm{ft}$.

Josikaea .................... 3 to $t \mathrm{ft}$.

Persian .................... 3 to $t \mathrm{ft}$.

Rothmagenesis (Rouen) ............ 3 to $4 \mathrm{ft}$.

LILACS-Named Varieties.

Belle de Nancy ............... 2 to $3 \mathrm{ft}$.

Double, rose and white. 1 ts to $24 \mathrm{in.} \quad 1.00$

Charles Tenth .............. 2 to $3 \mathrm{ft}$.

Reddish purple, single. 18 to $24 \mathrm{in.} \quad 1.00$

Ludwig Spaeth ............... to $3 \mathrm{ft}$. 1.25

Single, very dark purple. $\quad 18$ to $24 \mathrm{in.} \quad 1.00$

Mme. Lemoine ............... 2 to $3 \mathrm{ft} . \quad 1.25$

Double, large, white. $\quad 18$ to $24 \mathrm{in.} \quad 1.00$

Pres. Grevy ................ 2 to $3 \mathrm{ft.} 1.25$

Double, very fine, blue. $\quad 18$ to $24 \mathrm{in.} \quad 1.00$

Rubra d' Marley-Double, purple..... 2 to $3 \mathrm{ft}$. 1.25

LILACS-Newer Named Varieties.

Lamartine-Single, rose mauve...... 2 to $3 \mathrm{ft} . \quad 3.00$

Leon Ganbetta-Double, large, lilacrose ................... 2 to $3 \mathrm{ft} . \quad 3.00$

Montaigne-Double, pinkish mauve.... 2 to $3 \mathrm{ft}$. 3.00

Pres. Failliers-Double, pale lavender.. 2 to $3 \mathrm{ft}$. 3.00 
SHRUBS-Continued

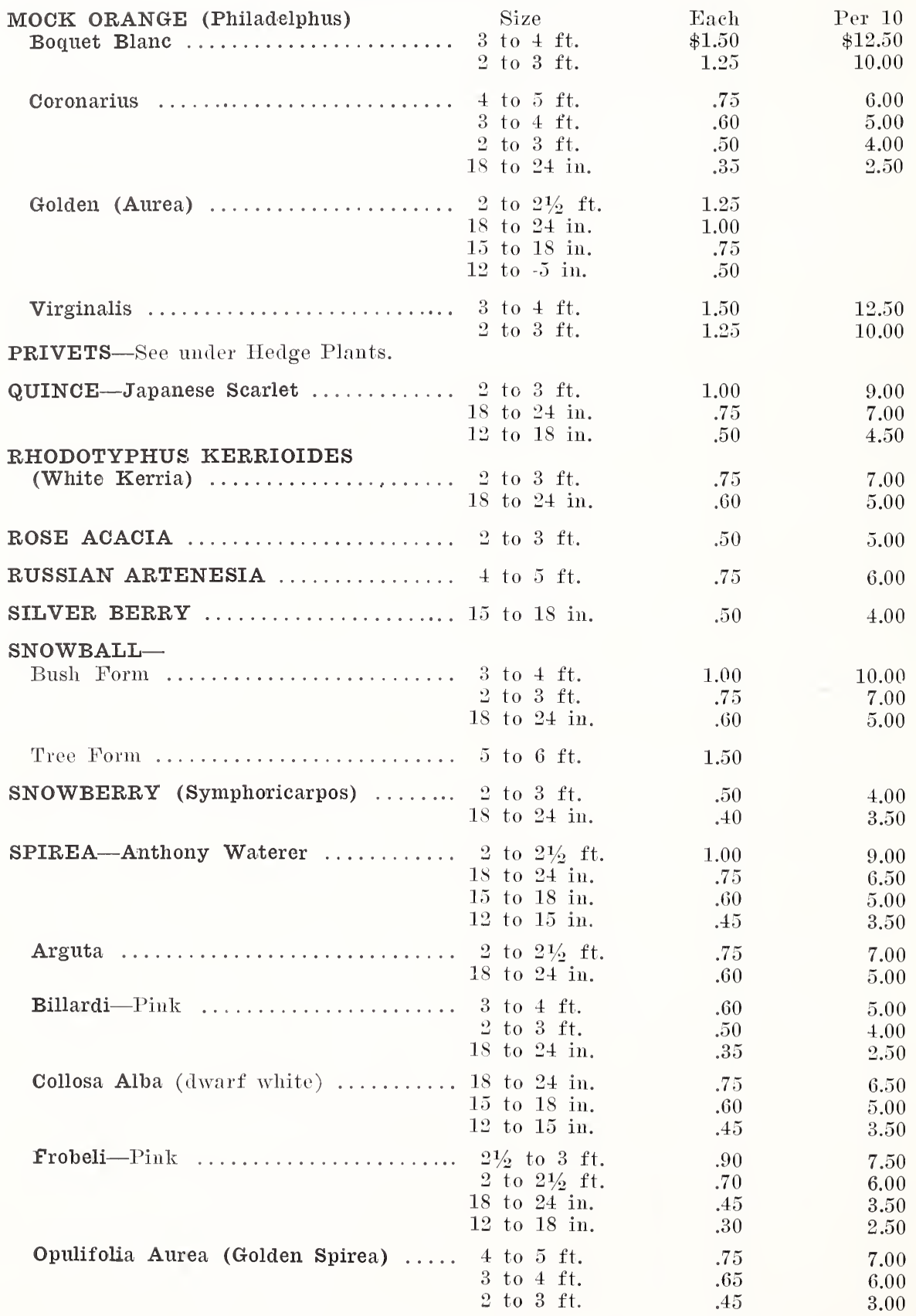




\section{SHRUBS-Continued}

\begin{tabular}{|c|c|c|c|}
\hline Sorbifolia (Ash leaved spirea)...... & $\begin{array}{l}\text { Size } \\
2 \text { to } 3 \mathrm{ft} \text {. } \\
18 \text { to } 24 \mathrm{in} .\end{array}$ & $\begin{array}{r}\text { Each } \\
\$ 0.60 \\
.50\end{array}$ & $\begin{array}{r}\operatorname{Per} 10 \\
\$ 5.00 \\
4.50\end{array}$ \\
\hline Van Houtti (Bridal Wreath) ........ & $\begin{array}{r}4 \text { to } 5 \mathrm{ft} . \\
3 \text { to } 4 \mathrm{ft} . \\
2 \text { to } 3 \mathrm{ft} . \\
18 \text { to } 24 \mathrm{in} . \\
12 \text { to } 18 \mathrm{in.}\end{array}$ & $\begin{array}{l}.80 \\
.70 \\
.50 \\
.35 \\
.25\end{array}$ & $\begin{array}{l}6.00 \\
5.00 \\
4.00 \\
2.50 \\
1.50\end{array}$ \\
\hline SUMAC-Aromatic (Fragrant Sumac)... & 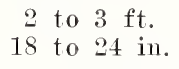 & $\begin{array}{l}.80 \\
.70\end{array}$ & $\begin{array}{l}7.00 \\
6.00\end{array}$ \\
\hline Staghorn Cut Leaved ............. & $\begin{array}{l}4 \text { to } 5 \mathrm{ft} . \\
3 \text { to } 4 \mathrm{ft} . \\
2 \text { to } 3 \mathrm{ft} . \\
18 \text { to } 24 \mathrm{in} .\end{array}$ & $\begin{array}{l}.90 \\
.75 \\
.50 \\
.40\end{array}$ & $\begin{array}{l}8.00 \\
7.00 \\
4.50 \\
3.50\end{array}$ \\
\hline TAMARIX $\ldots$. & $\begin{array}{l}3 \text { to } 4 \mathrm{ft} . \\
2 \text { to } 3 \mathrm{ft} .\end{array}$ & $\begin{array}{l}.60 \\
.45\end{array}$ & $\begin{array}{l}5.00 \\
3.50\end{array}$ \\
\hline $\begin{array}{l}\text { VIBURNUM . . . . . . . . . . . . . . . . . . } \\
\text { See also Snowball and Cranberry } \\
\text { Dentatum (Arrowwood). }\end{array}$ & $\begin{array}{l}3 \text { to } 4 \mathrm{ft} . \\
2 \text { to } 3 \mathrm{ft} . \\
18 \text { to } 24 \mathrm{in} .\end{array}$ & $\begin{array}{l}.90 \\
.75 \\
.50\end{array}$ & $\begin{array}{l}7.50 \\
6.00 \\
4.00\end{array}$ \\
\hline Lantana (Wayfaring tree) .. & 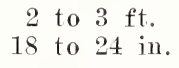 & .80 & $\begin{array}{l}7.50 \\
5.50\end{array}$ \\
\hline WEIGELIA-Eva Rathke $\ldots \ldots \ldots \ldots \ldots$ & $\begin{array}{l}2 \text { to } 3 \mathrm{ft} . \\
18 \text { to } 24 \mathrm{in} .\end{array}$ & $\begin{array}{l}1.25 \\
1.00\end{array}$ & $\begin{array}{r}12.00 \\
9.00\end{array}$ \\
\hline Rosea $\ldots \ldots \ldots \ldots \ldots \ldots \ldots \ldots \ldots \ldots$ & 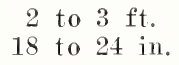 & .60 & $\begin{array}{l}5.00 \\
4.00\end{array}$ \\
\hline
\end{tabular}

\section{HEDGE PLANTS}

(See also Arborvitae and Spruce under Evergreens, and Russian Mulberry under Forest Trees)

\section{BARBERRY THUNBERGII (Japanese}

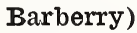

Heavy 3-yea

Size

Heavy 3-yea $21 / 2$ to $3 \mathrm{ft}$

Heavy 3 -year ...................... to $24 \mathrm{in}$.

Heavy 3 -year ....................

Seedlings (slender plants) .........12 to $15 \mathrm{in}$.

\section{PRIVETS-}

9 to 12 in.

Amur River North

3 to $4 \mathrm{ft}$.

2 to $3 \mathrm{ft}$.

18 to 24 in.

12 to $18 \mathrm{in.}$

Polish

3 to $4 \mathrm{ft}$.

2 to $3 \mathrm{ft}$.

18 to 24 in.

12 to $18 \mathrm{in}$.

Ibota

2 to $3 \mathrm{ft}$.

18 to 24 in.

Regal's

2 to $21 / 2 \mathrm{ft}$

18 to $24 \mathrm{in}$.

18 to 24 in.

12 to $18 \mathrm{in.}$
Each Pr 10 Pr 100 Pr 1000

$\$ 0.60 \$ 5.50 \quad \$ 50.00$

$\begin{array}{lll}.50 & 4.50 \quad 40.00\end{array}$

$\begin{array}{lll}.40 & 3.50 \quad 30.00\end{array}$

$\begin{array}{lll}.35 & 3.00 \quad 25.00\end{array}$

$7.50 \$ 60.00$

$6.00 \quad 50.00$

$\begin{array}{lll}.40 & 3.50 & 30.00\end{array}$

$\begin{array}{lll}.35 & 3.00 \quad 25.00\end{array}$

$\begin{array}{lll}.25 & 2.00 \quad 17.50\end{array}$

$\begin{array}{lll}.20 & 1.50 \quad 10.00\end{array}$

$\begin{array}{lll}.40 & 3.50 \quad 30.00\end{array}$

$\begin{array}{lll}.35 & 3.00 & 25.00\end{array}$

$.25 \quad 2.00 \quad 17.50$

$\begin{array}{lll}.20 & 1.50 & 10.00\end{array}$

$\begin{array}{lll}.40 & 3.50 \quad 30.00\end{array}$

$\begin{array}{lll}.30 & 2.50 \quad 20.00\end{array}$

$.75 \quad 7.00$

$.60 \quad 5.00$ 


\section{ROSES}

All plants offered are two-year field-grown bushes. One-half or more of the tops should be cut off and the bushes planted deeper than they stood in the Nursery.

\section{CLIMBING ROSES}

\section{(All need winter protection)}

AMERICAN PILLAR, 75c: Immense clusters; large, single, bright crimson, lighter center.

BALTIMORE BELLE, 50c: Blush-white, an old farorite, rather tender.

CRIMSON RAMBLER, 50c: Bright red, large clusters, the most popular climber. CLIMBING AMERICAN BEAUTY, 75c: Large rich carmine, somewhat fragrant. DR. VAN FLEET, 90c: Light pink, perfectly formed, pointed buds, long stems. DOROTHY PERKINS, 50c: Delicate pink, large clusters, vigorous and healthy. EXCELSA (Red Dorothy Perkins), 50c: Lighter red than Crimson Rambler, but more vigorous.

FLOWER OF FAIRFIELD, 75c: Ever-bblooming crimson rambler.

HIAWATHA, 5cc: Single, deep crimson with yellow center, very fragrant.

MEMORIAL, 50c: Glossy foliage with very fragrant, creamy white flowers.

PAUL'S SCARLET, 90c: Large, bright, pure red, semi-double, in elusters.

PRAIRIE QUEEN, 50c: Large globular, bright pink, one of the hardiest climbers. ROSA SETIGERA, 50c: The wild prairie rose, single, light pink flowers and bright red heps.

ROSIERE, 75c: A darker colored Thousand Beauties.

TAUSENDSCHON, 75c: Large clusters ranging from bright pink to pure white. WHITE DOROTHY PERKINS, 50c: The best pure white climbing rose.

\section{HARDY ROSES}

(Varieties which need no winter protection in Central Iowa)

BLANC DOUBLE DeCOUBERT, 75c: Rugosa, double white.

HANSA, 75c: Bright red, in clusters of 3 or 4 ; Rugosa foliage.

HARRISON YELLOW, 90c: Small bright yellow, early in spring.

HENRI MARTIN, 75c: Rosy red, mossed hearily, fragrant.

HUGONIS, \$1.50: A tall spring flowering shrub with yellowish flower.

KAMCHATKA, 75c: Bright red, double, foliage resembling Rugosa.

MAD. PLANTIER, 50c: Pure white, almost thornless, blooms in spring only.

PERSIAN YELLOW, 90c: Deepest yellow, Austrian brier.

ROSA BLANDA, 75c: Single, pink, tall upright grower, good shrub.

ROSA RUBRIFOLIA, 75c: A shrubby, perfectly hardy bush with reddish foliage and pink flowers, prefers partial shade.

ROSA RUGOSA, 75c: Single, large bright red, wrinkled, tough foliage, continuous bloomer, very large crimson heps.

SALET, 75c: Moss, large full rose pink.

SEVEN SISTERS, 50c: Double, large varying from light red to white.

WHITE MOSS, 75c: Large, pure white, fragrant, heavily mossed.

WHITE RUGOSA, 75c: White form of Rugosa.

\section{OTHER ROSES}

H. T. means Hybrid Tea; H. P. means Hybrid Perpetual. All these should have winter protection. The Baby Ramblers and H. T.'s are the most constant bloomers. AMERICAN BEAUTY, 90c: H. P., large globe shaped, crimson. 


\section{ROSES-Continued}

BABY RAMBLERS, 90c: Red, white or pink; not elimbers, but dwarf bushes.

Named. Varieties:

Clotilde Soupert, 90c:..Very full, pearly white shaded pink.

Gruss an Aachen, \$1.00: Very large, light rose overlaid with yellow.

Jessie, 90c: Glowing crimson with white eye.

LaFayette, \$1.25: Large brilliant cherry-crimson flowers.

Orleans, 90c: Geranium red with rose tint.

CONRAD F. MEYER, 90c: Iybrid Rugosa, delieate pink, strong upright grower.

EDWARD MAWLEY, 90c: H. T., very dark velvety crimson, inost fragrant.

ETOILE De FRANCE, 90c: H. T., large, cuppel, velvety crimson, very fragrant.

FRAU KARL DRUSCHKI, 75c: If. P., the very purest white, continuous bloomer.

GEN. JACQUEMINOT, 75c: H. P., scarlet-crimson, early and fragrant.

GEN. McARTHUR, 90c: II. T., sweetly scented, brilliant crimson-scarlet, very free bloomer.

GEO. ARENDS, 90c: H. P., large, fragrant, pink, called "Pink Druschki."

GOLDEN OPHELIA, \$1.00: H. T., a golden form of the Ophelia rariety.

GROOTENDORST, 90c: Hybrid Rugosa X, Baby Rambler; semi-double, bright red. GRUS AN TEPLITZ, 90c: H. T., clear crimson-scarlet, the most continuous bloomer. J. B. CLARK, 75c: II. P., very large, intense scarlet; vigorous grower. JOHN HOPPER, 75c: H. P., large, rosy red, fragrant, medium grower.

LADY HILLINGDON, 90c: H. T., long pointed buds opening apricot yellow.

LOLITA ARMOUR, \$1.00: Pernetiana, large, fragrant, chrome-yellow at base sliading to bright salmon.

LOS ANGELES, \$1.25: H. T., coral pink shaded coppery gold, moderately hardy.

MAGNA CHARTA, 75c: H. P., very large rosy pink, tinted carmine.

MRS. CHAS. RUSSEL, 90c: H. T., rosy carmine with rosy searlet center.

MRS. JOHN LAING, 75c: Large soft pink, pointed buds, vigorous grower.

MME. BUTTERFLY, 90c: H. T., a more brilliant Ophelia.

OPHELIA, 90c: H. T., salmon-flesh, fragrant, long stems, very productive.

PAUL NEYRON, 75c: H. P., very largest, clear pink, fragrant, thornless.

PRINCE CAMILIE De ROHAN, 75c: H. P., dark blood red, large, fragrant, rather weak grower.

RADIANCE, 90c: H. T., fine salmon pink, long stems, very productive.

RED RADIANCE, 90c: H. T., deep red, finest form, extremely productive.

SUNBURST, 90c: H. T., bright orange yellow, with paler edge.

SOLEIL D' OR, 90c: Orange yellow varying to ruddy gold, not continuous.

ULRICH BRUNER, 75c: H. P., large, fragrant, cherry red, vigorous.

\section{CLIMBING VINES}

(Two-year No. 1 plants except as noted)

\section{AMPELOPSIS (Ivy)}

\begin{tabular}{|c|c|c|}
\hline & Each & Per 10 \\
\hline Englemanni-Clings to smoothest walls & & $\$ 4.00$ \\
\hline Medium grade & .35 & 2.50 \\
\hline Veitchii (Boston Ivy) & 1.00 & 9.00 \\
\hline Medium grade ... & .75 & 6.00 \\
\hline
\end{tabular}

ARISTOLOCHIA (Dutchman's Pape), large leaf ..............25

small leaf $\ldots \ldots \ldots \ldots \ldots .60$ 


\section{CLIMBING VINES-Continued}

Each Per 10

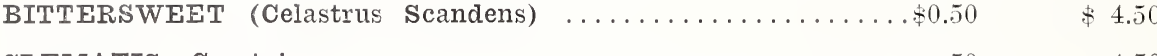

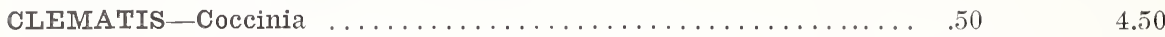

Paniculata ....................... $50 \quad 4.50$

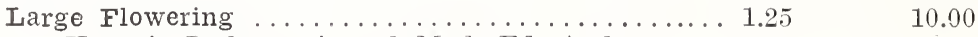

Henryi, Jackmanni, and Mad. Ed. Andre.

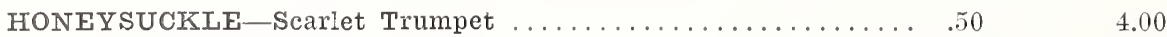

Medium grade ...............................

HOP VINE . . . . . . .

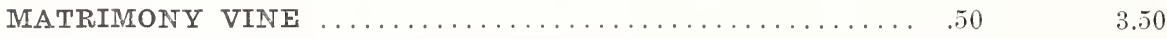

POLYGONUM AUBERTI (Silver Lace Vine)............. 1.25 10.00

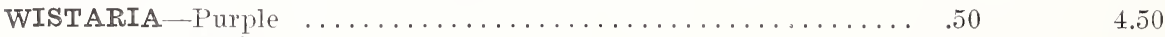

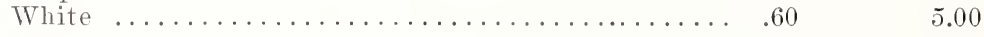

\section{PEONIES}

We do not keep a stock of the more expensive rarieties in storage for spring planting, so any order for them will be held till fall, which is the very best time to plant peonies.

Prices are for standard divisions of 3 to 5 eyes or buds. Undivided elumps figured on this basis.

ASA GRAY, \$1.00: Semi-rose type, mid-season, pink with carmine dots.

ADOIPHE ROSSEAU, \$1.50: Semi-double, early, brilliant red.

AGNES M. KELWAY, 40c: Crown type, early, pale rose with creamy center.

AVALANCHE, \$1.00: Crown type, late, very fine milk white.

AUGUSTIN D'HOUR, 75c: Bomb type, tall, mid-season, rich scarlet purple.

BARONESS SCHROEDER, \$1.25: Rose type, late, flesh color fading white.

COUROUNE D' OR, 50c: Semi-rose type, late, with white with yellow stamens.

CLAIRE DUBOIS, \$1.00: Rose type, tall, late, fine pink with glossy reflex.

DELACHEI, 75c: Rose type, late, brilliant dark maroon.

DENIS HELYE, 50c: Semi-rose type, mid-season, brilliant red.

EDUI.IS SUPERBA, 50c: Crown type, rery early, bright pink.

ENCHANTRESSE, \$5.00: Rose type, very late, creamy white.

ELWOOD PLEAS, \$4.00: Rose type, late mid-season, tall, light shell-pink.

FESTIVA MAXIMA, 50c: Rose type, early, pure white, tipped carmine.

FRANCOISE ORTEGAT, 75c: Semi-rose type, mid-season, deep crimson.

FELIX CROUSSE, 75c: Rose type, late mid-season, bright ruby red.

FRAGRANS, 4cc: Bomb type, mid-season, deep pink.

GOLDEN HARVEST, 40c: Bomb type, mid-seasoll, pink, creamy white center.

GRANDIFLORA, 50c: Rose type, late, very fine bright pink.

H. F. REDDICK, \$1.00: Semi-rose type, mid-season, brilliant crimson.

JENNY LIND, \$1.00: Bomb type, tall, mid-season, light pink interspersed with white.

JUBILEE, \$4.00: Rose type, very tall, white with delicate pink center.

KARL ROSENFIELD, \$1.25: Semi-rose type, mid-season, rich blood red.

LE CYGNE, \$15.00: Rose type, pure white, has the rery highest rating.

LADY ALEXANDER DUFF, \$3.50: Rose type, early, pink fading white. 


\section{PEONIES-Continued}

LIVINGSTONE, 75c: Rose type, late, deep pink, fine cut flower.

LATULIP, 50c: Semi-rose type, flesh pink fading white, red markings.

LOUIS VAN HOUTTI, 75c: Semi-rose type, bright violaceous red.

L' ESPERANCE, 50c: Rose type, very early rose pink.

MARIE LEMOINE, \$1.00: Rose type, very late, ivory white.

MARTHA BULLOCK, \$10.00: Rose type, tall, very large, rosy pink.

MAD. CHAUMY, 40c: Rose type, very late, bright rose.

MARECHAL VALLIANT, 50c: Rose type, very large, late, purplish red.

MIREILLE, \$1.00: Rose type, very late, milk white.

MAD. DE VERNEVILLE, 50c: Bomb type, mid-season, white, very choice.

MAD. EMILE GALLE, \$1.00: Rose type, late, pale pink, shaded lilac-rose.

MON. JULES ELIE, \$1.00: Bomb type, mid-season, glossy pink, extra fine.

MONS. MARTIN CAHUZAC, \$2.50: Semi-rose type, early, darkest deep maroon.

MODISTE GUERIN, 75c: Bomb type, mid-season, deep lustrous pink.

OFFICINALIS rubra plena, \$1.00: Very earliest, bright crimson.

OFFICINALIS rosea, $\$ 1.00$ : Very earliest, rose pink.

OFFICINALIS tenuifolia, \$1.50: Fern leaved, very earliest, bright crimson.

PASTEUR, \$2.00: Rose type, mid-season, very soft pink.

PRES. ROOSEVELT, \$1.00. Semi-rose type, mid-season, deep red.

PRIMEVERE, \$3.00: Bomb type, mil-season, tall, ereamy yellow.

RACHEL, \$1.00: Rose type, mid-season, brightest ruby red.

RICHARD CARVEL, \$4.00: Bomb type, early, very bright crimson.

ROSA BONHEUR, \$4.50: Rose type, dwarf, light violet rose flecked crimson.

RUBRA triumphans, 50c: Semi-double, early, red with yellow stamens.

SOLANGE, \$4.00: Rose type, mid-season, white shaded salmon.

THERESE, \$4.50: Rose type, mid-season, delicate satiny pink.

TOURANGELLE, \$5.00: Rose type, late, ereamy buff with salmon tints.

WALTER FAXSON, \$5.00: Semi-rose type, mid-season, distinct bright salmon rose.

\section{SINGLE AND JAPANESE VARIETIES}

AKALU, \$2.00: Japanese, carmine red with center saffron yellow, striped carmine. GERALDINE, \$1.50: Japanese, deep carmine violet.

KING OF ENGLAND, \$4.00: Japanese, rich ruby-red with narrow golden center petals.

MIKADO, \$1.50: Japanese, dark erimson with eenter erimson, tipped gold.

OFFICINALIS tenuifolia rosea, \$1.00: Single, pink.

PETITE RENEE, 75c: Japanese, light magenta.

SNOW WHEEL, \$4.00: Japanese, pure white throughout.

STANLEY, \$1.00: Single, large, dark brilliant crimson.

THE BRIDE, \$1.00: Single, large, white with yellow center.

\section{PHLOX}

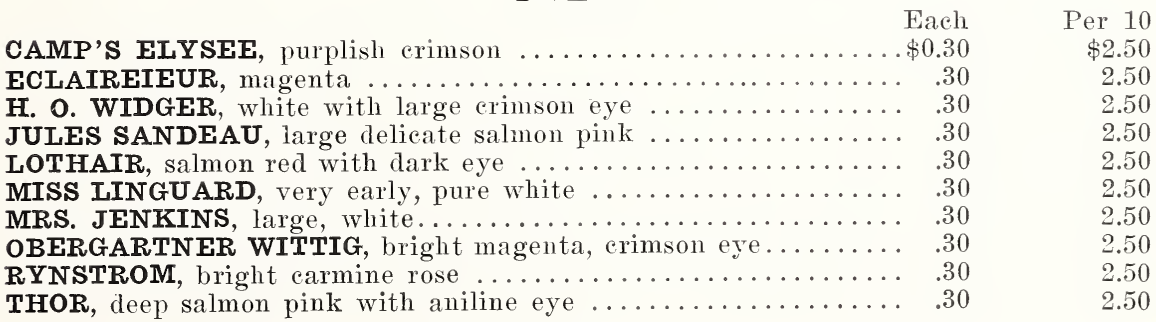




\section{IRIS}

Iris may be planted almost any time, but preferably not at or just previous to blooming time. Iris should be planted very shallow and on dry, well drained soil, except the Siberian varieties and other fibrous rooted kinds, which are moistureenduring. The effect is better if a group of one kind or color is planted rather than single plants of many colors.

Quantity Rates. Kinds priced at:

10 e each are $\$ 0.60$ per 10 and $\$ 4.00$ per 100 .
15 e each are .80 per 10 and 6.00 per 100 .
20 e each are 1.00 per 10 and 8.00 per 100 .
25 e each are 1.50 per 10 and 12.00 per 100.

S. denotes standards, the upright part of the flower; and F. falls.

DWARF IRIS, 5 to 12 inches high, very early, fine for borders.

Cyanea, 10c: S., rich blue; F., dark satiny purple, 6 inches high.

Schneekuppe, 30c: S. and F., pure white, 10 to 12 inches, rery fine.

Excelsa, 20c: S. and F., deep clear rellow, 8 inches.

INTERMEDIATE IRIS: Intermediate in height and season of blooming.

Helge, 15c: S. and F., lemon yellow with pearl shadings, large.

Ingeborg, 25c: S. and F., very fine large pure white.

Walhalla, 15c: S., light blue; F., velvety violet purple.

Maori King, 25c: S., richest golden yellow: F., relvety maroon.

\section{TALL BEARDED IRIS:}

Anna Farr, \$1.25: S., white bordered pale blue; F., white marked blue.

Crusader, \$1.00: S., light blue; F., deep violet blue.

Dalila, 50c: S., coppery blonze; F., velvety erimson.

Darius, 20c: S., canary rellow; F., lilac margined white.

Dr. Bernice, 20c: S., coppery bronze; F., velvety crimson.

Fairy, 15c: S. and F., white delicately bordered pale blue.

Flavescens, 15c: S. and F., pale sulphur yellow, sweetly scented.

Gypsy Queen, 15c: S., old gold shaded pearl; F., reticulated maroon.

Hiawatha, 30c: S., pale lavender; F., royal purple.

Honorabilis, 10c: S., golden yellow; F., brownish mahogany.

Kochi, 15c: S. and F., rich blackish purple, very large and fine.

Lent A. Williamson, \$1.00: S., lavender riolet; F., royal purple.

Loreley, 20c: S., light yellow; F., blue bordered cream.

Leonidas, 20c: S., clear mauve; F., rosy mauve.

Latendresse, 10c: S. and F., ageratum blue throughout.

Johan de Witte, 10c: S., bluish violet; F., deep riolet reined white.

Juniata, 25c: S., arching; F., flaring, clear blue throughout.

Kermesiana, 15c: Claret red, marked, medium size, endures moisture.

Lorengrin, 25c: S. and F., lilac rose.

IIa Mie, 50c: S. and F., white, frilled pale blue.

Mariposa, \$1.00: S., French gray; F., flaked purple.

Mary Garden, 30c: S., pale yellow flushed lavender; F., creamy dotted.

Mad. Chereau, 10c: S. and F., white, frilled pale blue, tall and late.

Mithras, 30c: S., light yellow; F., wine red bordered yellow.

Mother of Pearl, \$4.00: S. and F., pale bluish lavender, delicately tinted.

Monsignor, 30c: S., deep violet; F., purplish crimson, veined darker. 


\section{IRIS-Continued}

Mrs. Andrist, 30c: S., pure white; F., svelvety purple.

Mrs. H. Darwin, 15c: S. and F., pure white with purplish veins.

Mad. Pacquette, 20c: S. and F., bright rosy claret, ruffled, tall.

Navajo, 50c: S., light yellow shaded lavender; F., deep maroon.

Nibelungen, 30c: S., fawn; F., violet purple, veined purple.

Nokomis, 30c: S., pale lavender white; F., deep violet blue.

Pallida Delmatica, 25c: S. and F., light lavender violet.

Pallida Speciosa, 20c: S., dark lavender; F., light purple.

Park de Neuilly, 30c: S. and F., rich plum purple, large.

Pauline, 40c: S. and F., rich pansy purple.

Perfection, 30c: S., light blue; F., dark violet.

Princess Victoria Louise, 25c: S., sulphur yellow; F., rich plum bortered cream.

Prosper Laugier, 30c: S., light bronze red; F., velvety Bordeaux.

Queen Alexandria, 25c: S., fawn overeast lilac; F., lilac.

Queen of the Gypsies, 10c: S., brouze; F., purplish red.

Rheine Nixe, 25c: S., clear white; F., violet blue, edged white.

Shekinah, \$1.00: S. and F., beautiful soft yellow, tall.

Sherwin Wright, 30c: S. and F., golden yellow.

Silver King (Florentina), 15c: S. and F., white slightly tinted lavender.

Souvenier De Mme. Gandichau, \$2.00: S. and F., brilliant blaek purple.

Swatara, 50c: S., lobelia blue sufiused yellow; F., violet.

White Knight, 75c: S. and F., pure white, late.

Wyomissing, 30c: S.. creamy white suffused rose; F., deep rose.

Zua, 75c: S. and F., delicate lavender white, ruffled like fine crepe.

\section{SIBERIAN AND OTHER IRIS:}

Blue King, 15c: Siberian, clear blue with very delicate markings.

Geo. Wallace, 30c: Siberian, S., azure blue; F., marked white.

Longipetala Superba, 30c: Dainty lavender.

Mahogany, 40c: Japanese, dark red.

Orientalis, 15c: Siberian, similar to Blue King, but a little darker.

Orientalis Gigantea, 50c: Ivory white, very tall.

Pseudacorus, 30c: Wild, yellow, for the waterside.

Snow Queen, 15c: Siberian, ivory white with yellowish throat.

\section{OTHER HARDY PERENNIALS}

The measure given is the height they grow, and the dates, the blooming period. Most perennials can be moved well either fall or spring, and many of them through the summer. Prices, unless otherwise given: Field-grown plants, $30 \mathrm{c}$ each, $\$ 2.40$ per dozen, $\$ 15.00$ per $100-3$ or more at dozen rates, and 25 or more at inundred rates.

ACHILLEA (Milfoil or Yarrow)

The Pearl, 1 ft., pure white, all summer.

ALLYSSUM Saxitile (Basket of Gold) - $1 \mathrm{ft}$, bright yellow, early spring, fine for rockery or borders.

ASTERS-Mauve Cushion, 35c: Dwarf, delicate mauve, late fall.

Alpine Sub-Coeruleus, $1 \mathrm{ft.}$, bluish violet, June and July.

BALLOON FLOWER (Platycodon), 1 to $2 \mathrm{ft}$, August and September, either white or light blue. 


\section{OTHER HARDY PERENNIALS-Continued}

BLEEDING HEART, 60c: (Dicentra Spectabilis), 1 to $21 \% \mathrm{ft}$, early, shadeenduring.

BLEEDING HEART, FERN LEAVED, 50c: (Dicentra Eximia), dwarf, everblooming, finely cut foliage.

CAMPANULA (Bellflower)

Carpatica (Harebell), 8 in., clear blue, June to October.

CHRYSANTHEMUM-Hardy

Brune Poitevine, deep velvety red, September and October.

Carmelite, golden yellow, September and October.

Idolph, salmon pink, September and October.

Mrs. H. Harrison, bluish pink, October.

October Gold, rich golden bronze, October.

Oconto, pure white, October.

Old-Fashioned-Pink October and November.

White October and Norember.

Yellow October and November.

COLUMBINES (Aquilegia)-White - $2 \mathrm{ft.}$, early spring.

Coerulea $2 \mathrm{ft}$, blue shades.

Common American 2 ft., red and rellow.

DAISY-Arctic, dwarf, pure white, September and October.

Giant, 3 to $4 \mathrm{ft}$., July to September.

Double White Shasta, medium size, all summer.

Shasta, 1 to $2 \mathrm{ft}$., September and October.

DELPHINUM (Larkspur)

Belladonna, 3 to $4 \mathrm{ft}$., light blue, all summer.

Chinese Blue, $2 \mathrm{ft}$., finely cut foliage, gentian blue, all summer.

Chinese White, $2 \mathrm{ft}$, finely cut foliage, white, all summer.

Gold Medal Hybrids, $4 \mathrm{ft}$., mixed colors, all summer.

\section{DIANTHUS}

Barbatus (Sweet William)

Alba, white, $1 \mathrm{ft.}$, early summer.

Diadem, crimson, white margin, 1 ft., early summer.

Pink Beauty, salmon pink, 1 ft., early summer.

Plumarius (Clove Pinks)

Mixed colors, dwarf, grasslike foliage, early spring.

FUNKIA, BLUE DAY LILY, PLANTAIN LILY

Coerulea, 11/2 ft., July, blue drooping flowers.

GAILLARDIA, 1 to $2 \mathrm{ft}$, all summer, red, yellow, and orange blended.

GOLDEN GLOW, 4 to $6 \mathrm{ft}$., August, large golden yellow flowers.

HEMEROCALLIS (YELLOW DAY LILY)

Flava (Lemon Lily), 21/2 ft., May and June, clear vellow.

Fulva (Brown Lily), 3 to 5 ft., coppery orange and crimson, July.

Thunbergii, $2 \mathrm{ft.}$, yellow, July.

Florham, 40c: 3 to $31 / 2 \mathrm{ft}$, very large, rich yellow, July.

Kwanso, 3 to $4 \mathrm{ft}$., double, golden bronze, July.

HIBISCUS, 4 to $5 \mathrm{ft}$., clear rose colored, 6 in. flowers, July to September.

HOLLYHOCKS, Assorted colors, 4 to $7 \mathrm{ft}$., August and September.

POPPY-Iceland, 1 to $2 \mathrm{ft}$., mostly yellow.

Oriental, $2 \mathrm{ft}$., large scarlet flowers with black centers, June.

STONE CROP (Sedum or Live Forever)

Spectabile, 1 ft., bright pink, August and September.

Sieboldi, Japaness, 40c: 6 inches, bright pink, September. 


\section{OTHER HARDY PERENNIALS-Continued}

\section{THALICTRUM}

Adiantifolium, 40c: 1 to $2 \mathrm{ft}$, yellowish, June and July.

Glaucum, 40c: 1 to $2 \mathrm{ft}$., pale yellow, July and August.

VERONICA. (Speedwell)

Longifolia, 2 ft., deep blue, July till frost.

Spicata, 2 ft., deep blue, June.

YUCCA Filametosa, 50c: 4 to $7 \mathrm{ft}$., large pancles, bell-shaped, white flowers in July. Extra heavy size, $75 c$.

\section{FOREST TREE SEEDLINGS}

\begin{tabular}{|c|c|c|c|}
\hline Green Ash and Soft Maple .......... & $\begin{array}{l}\text { Size } \\
2 \text { to } 3 \mathrm{ft.} \\
8 \text { to } 24 \text { in. } \\
2 \text { to } 18 \text { in. }\end{array}$ & $\begin{array}{c}\text { Per } 100 \\
\$ 4.00 \\
3.00 \\
2.25\end{array}$ & $\begin{array}{r}\text { Per } 1000 \\
\$ 35.00 \\
25.00 \\
20.00\end{array}$ \\
\hline$\cdots \cdots \cdots \cdots \cdots \cdot \begin{array}{r}2 \\
18 \\
12\end{array}$ & $\begin{array}{l}2 \text { to } 3 \mathrm{ft} . \\
8 \text { to } 24 \mathrm{in} . \\
2 \text { to } 18 \mathrm{in} .\end{array}$ & $\begin{array}{l}2.50 \\
2.00 \\
1.50\end{array}$ & $\begin{array}{l}22.00 \\
18.00 \\
12.50\end{array}$ \\
\hline Black Walnut and Butternut $\ldots \ldots \ldots \ldots 18$ & $\begin{array}{l}8 \text { to } 24 \text { in. } \\
2 \text { to } 18 \text { in. }\end{array}$ & $\begin{array}{l}7.00 \\
4.50\end{array}$ & $\begin{array}{l}60.00 \\
40.00\end{array}$ \\
\hline Carolina Poplars (1-year whips)......... & $\begin{array}{l}5 \text { ft. } \& \text { up } \\
4 \text { to } 5 \mathrm{ft} \text {. } \\
3 \text { to } 4 \mathrm{ft} . \\
2 \text { to } 3 \mathrm{ft} .\end{array}$ & $\begin{array}{l}8.00 \\
7.00 \\
6.00 \\
4.50\end{array}$ & $\begin{array}{l}75.00 \\
60.00 \\
50.00 \\
40.00\end{array}$ \\
\hline Honey Locust $\ldots \ldots \ldots \ldots \ldots \ldots \ldots \ldots \ldots$ & $\begin{array}{l}8 \text { to } 24 \mathrm{in.} \\
2 \text { to } 18 \mathrm{in.}\end{array}$ & $\begin{array}{l}3.50 \\
2.50\end{array}$ & $\begin{array}{l}30.00 \\
20.00\end{array}$ \\
\hline Russian Mulberry and Hardy Catalpa... & $\begin{array}{l}2 \text { to } 3 \mathrm{ft} . \\
8 \text { to } 24 \text { in. } \\
2 \text { to } 18 \text { in. }\end{array}$ & $\begin{array}{l}3.00 \\
2.00 \\
1.50\end{array}$ & $\begin{array}{l}25.00 \\
18.00 \\
12.50\end{array}$ \\
\hline
\end{tabular}

\section{GRAFTED NUT TREES}

NUT TREES are more permanent, more ornamental, and will be more profitable than any other class of trees one can plant. It requires four to eight years to get a grafted nut tree ready for sale. This makes the first cost seem high. However, when we consider that it requires but one-half to one-third as many nut trees as fruit trees to plant an acre, the first cost is really less and the nut trees will produce profitably from two to six times as long; besides, when they reach maturity they have a great value for lumber and fuel.

Nuts supply all the essentials of human food and are coming into more general use. In the future agriculture, nut erops will have an important part. Why plant Box Elder, Elms and Poplars which can give us but leaves and a poor quality of fuel?

The one dependable way to secure valuable varieties of nut trees is to plant only grafted trees.

TRANSPLANTING nut trees successfully depends greatly upon securing trees which have been transplanted once or twice before they were grafted.

Cutting back the top severely is another very essential requirement. Then let the tree grow as it will for two years, so the root will become well established. Then trim and train to one shoot until the desired height for the top is reached. 


\section{GRAFTED NUT TREES-Continued}

We will properly eut back the tops of any nut trees we send out, without extra charge, and will wax the cut surfaces with our specially prepared tree wax, if requested to do so.

It is a decided advantage to plant nut trees, which have been grafted, four to six inches deeper than they stood in the nursery, so in case of accident to the top (rabbits or mice girdle them), there will be enough of the graft in the ground to throw up a new shoot and save the variety.

HICKORIES AND HICCANS. No more trees of these are available for spring 1926. The varieties we grew were mostly Fairbanks, Cedarapids and Stratford Hickories, Burlington, Des Moines and Marquardt Hiceans, and Ehmer and Witte Pecans.

\section{BLACK WALNUTS:}

Thomas-A native of Pennsylvania. This is the best known and most planted of the grafted varieties. The tree is hardy, very vigorous growing, productive and very young bearer; switches of but one year's growth often bearing the next season. The nut is large, quite thin shelled and easily cracked, yielding ten pounds per bushel of light colored meats of pleasing quality.

Ohio-A vigorous growing, productive variety, named for its native state. The nuts are somewhat flattened and pointed, large and with a fairly thin shell, which cracks so a good percentage of the kernels come out in halves. The meats are light colored and of fine flavor.

Stabler-A native of Maryland and probably not as hardy as Ohio or Thomas, but a good grower and productive. The nut is medium in size and its shell very thin, often not divided so the meats can be extracted whole. This is far the easiest variety to crack without breaking the meats.

Schwartz-An Iowa variety which we believe one of the very best of all. The trees are very vigorous, well formed and young bearers. The nuts are large, thin shelled and the meats crack out in halves. No variety we have tested excels this one.

All are one-year tops grafted on transplanted stocks.

\begin{tabular}{|c|c|c|c|}
\hline $\begin{array}{l}\text { PRICES:. } \\
\text { Thomas .. }\end{array}$ & $\begin{array}{c}4 \text { to } 5 \mathrm{ft} . \\
\$ 2.25\end{array}$ & $\begin{array}{c}3 \text { to } 4 \mathrm{ft} . \\
\$ 2.00\end{array}$ & $\begin{array}{r}2 \text { to } 3 \mathrm{ft} . \\
\$ 1.50\end{array}$ \\
\hline Ohio $\ldots \ldots \ldots \ldots \ldots \ldots \ldots \ldots \ldots \ldots \ldots \ldots \ldots$ & 2.25 & 2.00 & 1.50 \\
\hline 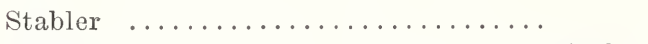 & 2.25 & 2.00 & 1.5 \\
\hline Schwartz $\ldots \ldots \ldots \ldots \ldots \ldots \ldots \ldots \ldots . \ldots \ldots$ & 2.75 & 2.50 & \\
\hline
\end{tabular}

FILBERTS have not been sufficiently tested that we can recommend them for general planting, but a good number of varieties are very promising and we can furnish an assortment of the best named varieties at $\$ 1.50$ each or $\$ 12.50$ per ten.

HAZLENUTS. Another season we hope to have stock of the large American Hazlenuts ready to offer. These compare very favorably with the filberts in size, are absolutely hardy and beautiful shrubs. 

